\title{
Judith Butler: disturbance, provocation and the ethics of non- violence
}

\author{
Fiona Jenkins
}

To be human seems to mean being in a predicament that one cannot solve.

- Judith Butler, Giving an Account of Oneself, p. 103

\section{Troubled thought}

Judith Butler's Gender Trouble (1990) profoundly shaped critical inquiry in the decade that followed its publication across many intellectual fields, and it is undoubtedly Butler's most widely read book. When I came across it belatedly in 1995, I read it cover to cover in a day, intrigued and provoked by the ideas I encountered. Above all, however, I remember that I found myself repeatedly disturbed by the photograph on the cover, to which I would turn again and again, pausing from my reading, and puzzling over how what the image seemed to me to show might correlate with what I took the text to say. The front cover of the edition I read shows in grainy black-and-white a girl and a boy, aged about seven or eight, but the boy is in girls' clothing - a dress and ruffled pinafore matching those of the slighter taller girl next to him. At least, I took him to be a boy. It looked to me like a boy's face. Yet when I eventually turned to the back cover, I learnt that the photo is captioned 'Agnes and Inez Albright'. Are these, then, really two girls - one of whom looks like a boy-or does the boy not only wear girls' clothes but bear a girl's name? And why did it bother me that I neither knew the answer nor found it easy to square my experience of the image with what Butler seems to argue in this work?

In the discussion that follows, I take the trouble this image presents as a point of departure for an initial question about how best to read Butler's work-one that turns in important ways on what we make of the idea of trouble that is at the centre of her ethical and political thought. ${ }^{1}$ I shall argue that to trouble and to be troubled, to be willing to remain in the space of trouble, are elements

1 A recent publication by Samuel Chambers and Terrell Carver notably takes up the idea of trouble in Butler's work as a way of positioning her distinctive contribution to political theory. See Judith Butler and 
in Butler's valorization of and plea for the value of disturbance. Disturbance of the kind that Butler is interested in is often experienced as intolerable, indeed as a provocation or assault on the self that demands a violent reaction in return. In her most recent work, however, Butler has sought to elaborate how the experience of disturbance might be met with non-violence rather than violence, through a struggle to avoid threatening another, in reiteration of one's own experience of being threatened. We shall see that for Butler, violence belongs within reiterative patterns internal to our perceptions of what is normal or natural, and that non-violence foregrounds the ethical question of how to respond in a scene in which that question tends to vanish behind a sense of what it is 'necessary' to do. Let me begin, however, from the problem of reading and how a certain way of reading Butler would lead one to wonder about the nature of the disturbance presented by this image.

Perhaps the most obvious message one draws from reading Gender Trouble is that in this work Butler is advocating some kind of radical constructivism with respect to sexual difference-radical in the sense that she suggests the questions feminism has raised about the naturalness of gender differences must come to inflect sexual difference as well, making the very idea that there are two 'natural' sexes uncertain. Gender Trouble argues that we have to go beyond the tacit or explicit acknowledgment that feminism has made of the existence of two clear biological sexes, while holding that these are distinct from and indifferent to the acculturated gender differences we might properly take as the target of political change and re-education. For 'sex' is itself, Butler argues, a gendered category: 'Gender ought not to be conceived merely as the cultural inscription of meaning on a pregiven sex...gender must also designate the very apparatus of production whereby the sexes themselves are established.' ${ }^{2}$

If sex appears, as we might think, ordinarily, as an aspect of the natural or biological world, Butler's argument is that it is because it has been constituted as such. Sex has been constructed as the 'radically unconstructed', as that nature on which culture acts; and yet its delineation is profoundly shaped by modes of normativity that regulate a whole range of social and sexual behaviours. But - and this is one way in which the idea is so provocative - if the 'radically unconstructed' is itself a construction, it might seem as though the 'reality' of sexual difference (and in all that seems to be its biological or material giveness) simply disappears. Under the ruffled pinafore, behind the name, would lie no truth at all.

Political Theory: Troubling politics (2008, Routledge, New York and Abingdon). Penelope Deutscher has a very useful discussion of Butler's use of 'trouble' in Yielding Gender: Feminism, deconstruction and the history of philosophy (1997, Routledge, New York and London: see ch. 1).

2 Butler, Judith 1990, Gender Trouble, Routledge, New York, p. 7. 
The assumption that Butler's thought led to the denial of some crucial reality of sexual difference inspired the first wave of criticism of Gender Trouble. It seemed to Butler's critics that her application of deconstructive thinking to the question of gender had led to a kind of indifference to bodies; and the material as well as the ethically and politically salient aspects of embodied sexual difference had been collapsed into a plurality of possibilities. In Butler's version of things, it seemed, we might discover these to have been either absurdly reduced to the arrangements of ' $\mathrm{X}$ ' and ' $\mathrm{Y}$ ' chromosomes or narrowed purely by our cultural commitments to 'hetero-normativity' - that is, to the field of normalcy and intelligibility defined by a certain arbitrary arrangement of sexuality and bodily morphology, and privileging heterosexual arrangements of desire. Despite the apparent radicalness of this approach, however, this meant that Butler ended up in a position that echoed the lack of material thinking inherent to the legacies of liberal feminist politics she had herself set out to critique-and either lent an improbable degree of social malleability to all aspects of identity or gave credence to the idea of a social monolith constructing every aspect of what we are. Building on these objections, two further lines of criticism - whose mutual contradictoriness is itself revealing - shaped the response to Gender Trouble. These circled around the claim made in that work that gender is 'performative', or rather that gender is to be understood as 'an identity tenuously constituted in time, instituted in an exterior space through a stylized repetition of acts'. ${ }^{3}$ On the one hand, this account was taken to indicate the presence of a subject who would control and deploy the 'appearances' of gender at will, as if selecting clothes from a closet; while on the other, Butler's account of the normative inscription of gendered life-which, she argues, is itself responsible for producing socially 'viable' subject positions - was taken to be deterministic, to strip the subject of any agency to contest the norms by which social existence constrains and captures us. ${ }^{4}$

There are answers to these objections in Butler's works subsequent to Gender Trouble, which I outline below. ${ }^{5}$ For now, I simply want to note that my own first experience of the sense of unease Butler's radical text gives rise to was in some respects like Butler's critics, but centred on an odd experience of its cover image. My disturbance, however, did not exactly take the form of an objection;

3 Ibid., p. 140.

4 The most scathing version of these latter objections was penned by Nussbaum, Martha C. 1999, 'The professor of parody', The New Republic, 22 February 1999, vol. 220, no. 8, pp. 37-46. Similar objections are mounted against Butler by Seyla Benhabib, in Butler, Judith, Benhabib, Seyla, Fraser, Nancy and Nicholson, Linda 1995, Feminist Contentions, Routledge, New York and London.

5 Also note that there are many excellent discussions in the secondary literature on Butler that aim to clear her of these charges. See, for instance, Chambers and Carver, Judith Butler and Political Theory, ch. 3, pp. 51-71; Lloyd, Moya 2007, Judith Butler, Polity, Cambridge and Malden, pp. 57-74. The objections do, however, still surface. See Kirby, Vicki 2006, Judith Butler: Live theory, Continuum, London and New York, for a sustained argument. See also my critical engagement with the latter: Jenkins, Fiona 2008, 'Giving an account of Butler', Australian Humanities Review, vol. 45. 
rather, the image made me feel uneasy. Because I initially took Gender Trouble to argue for the radical contingency of gender norms in a sense that would imply that its text would itself produce a transformation in perception, my insistent sense of a question in response to the photograph on its cover - which exercised a compulsion that in no way dissipated through my reading - seemed to be misplaced and inept. Some of my response took the form of self-accusation. Was it my own implacable conservatism that was revealed in the recurrent either/or that seemed to me posed by the picture? Was I seized by homophobic norms? Why the depth of my evident attachment to the frame of gender reference that forced the either/or: either a boy with a girl's clothes and name or a girl with a boy's face? And yet, the materiality of sexual difference seemed to be evidenced in the force of this question and through the perceptual signs by which one reads the norm, even while acknowledging the possibility of deviation from it. Like Butler's first critics, to me, there seemed something dishonest in denying this. Nonetheless, and perhaps by virtue of the self-accusation that the narrowness of my response seemed to entail, I wanted the text to show me how I could stop seeing in this way. I wanted it to expose the limits of the discursive frame of the interpretation that compelled my question, as if to produce a revelation that would break with its force.

If I return now, however, to reconsider how to engage the girl/boy in the cover photograph of Gender Trouble with his/her anomalies of face, clothes and name, and to ask what my troubled experience with the photograph might show, it is because I find it important to the ethico-political terrain at stake here to register my desire for both some sudden Gestalt-switch provided through the argument of the text and the specific nature of its thwarting or failure. For it was not simply the case that multiple possibilities of gendered being opened up to my eyes as the force of the laws of intelligibility by which I read the image receded in the wake of criticism. Rather, exposed to the questions the photograph poses through the terms of engagement offered by the text, my sense of being compelled by the image precisely intensified. I turned to look at it again and again. Perhaps, then, what the image and my being troubled by it show is something that needs to be approached in another way. It is as if the image itself cannot represent anything that exceeds my normative frame for reading it (a frame registered in the insistent question: boy or girl, boy or girl?). But the thought I want to explore here is that the image disturbs, that I kept returning to it, is in a sense precisely what matters and what - rather than the depiction of a gender anomaly of one sort or another - makes it an apt image for the cover of this book, foregrounding the 'trouble' that is gender. The image does not 'depict' that trouble; rather, as indexed through the very gesture of unsettlement, something happens through the image - a movement whereby the image exceeds what it can represent and sets in motion a disturbance. 
The question I am addressing here is what is at stake in the process of unsettlement of norms, of seeing and relating to the world and finding one's own self a part of that circuitry. Butler often refers to the contingencies of the organisation of gender and other social norms in ways that intend to challenge the sense of necessity or naturalness that attaches to them. Yet when we speak of the 'contingent' organisation of social facts, we are very liable to presume an image of what this means that positions us in relation to the field of meaning as though we stand outside it, as conscious intentional subjects capable of 'seeing through' social illusions to reach a better truth, and of changing and remaking ourselves in its light. Yet, as I outline more fully below, it is just this picture of subjectivity (and the role it has played in feminist gender politics) that Butler rejects, along with its tacit positioning of selves outside the field of sociality structured as normative life. It is certainly the case that the project of social transformation is at the heart of Butler's work, and notably within this the aim of creating what she calls more 'liveable' spaces for those whose lives are systemically assaulted by the regulative action of norms - centrally including those of gender - which confer the fundamental terms by which we are recognised as subjects at all. The question of the liveable life is at once personal (what makes my life bearable?) and political (what makes the lives of others bearable?). Liveability is at risk where there are strong commitments to 'what constitutes the human, the distinctively human life, and what does not'. ${ }^{6}$ The history of exclusion and punishment that has attended the sexual transgression of heterosexual norms is exemplary for Butler of the abjection and 'social death' by which certain lives are marked; and her ethical and political commitments are shaped by challenging the contemporary exclusionary articulations of which bodies matter, and which, conversely are 'dematerialised' and exposed to violence. Such violence goes unacknowledged to the extent that it is viewed as justified or warranted by its power to restore a normal or natural order; and in the next section, I chart Butler's treatment of how violence 'disappears'. The question that I am raising before this, however, is how Butler's critical and transformative project is best described. If we aim to create more 'liveable' spaces, are we aiming to increase the 'possibilities' of being in some numerical sense? And if not precisely this, what is intended to flow from opening up the social field to the sense of its own contingency? How, given Butler's interest in the question of what 'qualifies a body for life within the domain of cultural intelligibility'7 (a question that touches constantly on the violence accompanying the normative), does a reenvisioning of ethical, political and critical thinking take place that can include her radical reassessment of the social terms of embodiment, of agency and of subjectivity?

6 Butler, Judith 2004, Undoing Gender, Routledge, New York and London, p. 17

7 Butler, Judith 1993, Bodies that Matter: On the discursive limits of 'sex', Routledge, New York and London, p. 2. 
The idea I shall seek to develop in this essay (and as a way of approaching what I would characterise as a key dimension of Butler's contribution to contemporary thought, one that enables us to link her early writing on gender as a place of 'trouble' to her more recent concerns to sketch the contours of an ethic of nonviolence in the context of a world obsessed by the 'war on terror') is that we need to pay attention to the unconventional terms of Butler's transformative critical project and to be very wary of reading her interest in revealing the 'contingency' of existing social arrangements as though this entails that these could simply be shrugged off or transcended. ${ }^{8}$ Indeed, the idea that in postulating 'gender trouble' Butler is simply exposing a contingent social organisation of the gendered world, premised on the fact that such a world is socially 'constructed', is apt to mislead in consequential ways. In particular, the very idea of 'construction' belongs to a frame of intelligibility that is highly overdetermined by the philosophical dualisms of freedom and necessity, subject and object, mind and body. Here we are led by the grammar of language itself to imagine: 1) a subject 'doing' the construction; 2) an agency whose freedom must be prior to constraints; and 3) a body whose existence is ultimately defined by its material recalcitrance to human making and opposed to subjectivity. These aspects of language and thought - first observed and analysed by Nietzsche as key elements in moral thinking ${ }^{9}$ - conjoin to reassert the schema of thinking that Butler is in fact seeking to deconstruct.

Some of these issues are directly addressed in the introduction to Bodies that Matter (1993) (which reads as a 'reply to my critics') and argues for thinking the term 'construction' only through the term 'materialisation':

What I would propose in place of these conceptions of construction is a return to the notion of matter, not as site or surface, but as a process of materialization that stabilizes over time to produce the effect of boundary, fixity and surface we call matter...[C]onstruction is neither a single act nor a causal process initiated by the subject...Construction not only takes place in time, but is itself a temporal process which operates through the reiteration of norms; sex is both produced and destabilized in the course of this reiteration. ${ }^{10}$

\footnotetext{
8 Penelope Deutscher (Yielding Gender, p. 15) puts the point neatly: 'showing gender to be a deconstructible category may mean resisting its naturalisation and normalisation. But there is a world of difference between this and the optimism that gender categories, because they are deconstructible are discardable fictions.'

9 These ideas about the relation of language and moral thought appear in a range of guises throughout Nietzsche's work, but see, in particular, a text that is often cited by Butler: On the Genealogy of Morals (First essay, section 13), which treats the 'misleading influence of language' in positing a subject or a 'doer' who stands behind the deed, and is the locus of a form of moral responsibility that enables someone who feels injured to blame another who is 'responsible' for it.

10 Butler, Bodies that Matter, pp. 9-10. For a highly critical discussion of this move in Butler, again see Kirby, Judith Butler, pp. 65-70.
} 
It is only when we take seriously the idea of a process of materialisation that is simultaneously productive and destabilising that the ethical space Butler's thought seeks to open up begins to develop its contours. 'Boundary, fixity and surface' could be an 'effect', but they are, precisely for that, effective, not mere effects. ${ }^{11}$ For this reason, it is necessary to register that the field of appearances is a force-field of relations - neither something superficial nor something supervening on a 'deeper' reality. Again, the ideas at stake here were integral to Nietzsche's thought and at the root of his profound influence on the French post-structuralist thinkers from whom Butler takes most direction in her work: Derrida and Foucault.

Thus, for instance, in this analysis, as elsewhere in Butler's thought, crucial work is being done by an account elaborated in Derrida's early work on the iterability of signs, which also tries to capture the 'force-field' of meaning by considering the performative dimensions of language. Thus Butler's treatment of gender as 'an identity tenuously constituted in time, instituted in an exterior space through a stylized repetition of acts' maps almost directly onto what Derrida has to say about the temporalised and spatialised structure of writing, whose character (he argues) emerges as fundamental for all meaning only when we give up on (or deconstruct) the assumption that the primary instance of meaning is one that owes its force to the intentional act of a conscious subject. ${ }^{12}$ Derrida's argument comprises two elements that are especially important for Butler: first, that given the dependence of all meaning on iterative structures, meaning cannot ever be fully 'stabilised' over time, although the attempt to do so finds expression in 'ideals' imagined to be able to govern the field of meaning; second, that all signification has a 'material' inscription (as Derrida famously argues, it is like writing as opposed to speech, or rather, speech is like writing in its dependence on a material form that cannot be taken to be controlled or centred by intentional subjectivity).

The first point is taken up by Butler as part of her account of gender norms as 'idealisations' supposed to be able to stand above and 'govern' the field of meaning, rendering stable, regular and timeless what is unstable, irregular and temporal. But it also inspires her account of how a 're-signification' of norms becomes possible, in so far as the 'rupture' inherent to each re-instantiation constitutes an opportunity where things might happen differently. Iteration entails that meaning is always breaking with its 'original' context; indeed,

11 Gayle Salamon has a useful discussion of how the mistake that is made here is bound up with the misconstrual of fantasy, taken to be a term opposed to, and inferior to, reality, rather than rendering fantasy in the psychoanalytic sense as an enabling condition of the subject. See Salamon, Gayle 2004, 'The bodily ego and the contested domain of the material', differences: A journal of feminist cultural studies, vol 15, no. 3 (Fall), p. 115.

12 See Derrida's essay 'Signature, event, context' (1982, Margins of Philosophy, Harvester Press, Sussex, pp. 307-30). 
it entails that there is no 'original' context but only an imaginary attempt to stabilise discourse by imputing to a founding moment the capacity to govern the unknowable future set of inscriptions of the sign. The material inscription of signs is also the scene of their mutability and deformability. The second point is taken up, then, when in Bodies that Matter Butler elaborates an account of the body that aims to refine the theory of the social inscription of gender by appealing to the passage of signification and materiality through one another, in a rhetorical figure of 'chiasmus' or crossing. To come back to the idea of a body's 'boundary' as 'effect', Butler argues that the norms of sex performatively constitute the sexed materiality of the body as a result of the reiterative and citational practice by which discourse produces the effects that it names; but such materialisation is never quite complete - 'bodies never quite comply with the norms by which their materialization is impelled' ${ }^{13}$ Here we encounter a doubled thought about how norms 'work' and thus might be 'unworked'. On the one hand, the very failure of the norm to fully materialise explains the compelling sense of needing to fulfil it, to 'realise' what it demands. On the other hand, this temporal inscription of the norm allows for another possibility of response.

For the unworking inherent to the life of norms to take place, Butler argues, it is necessary that norms become 'rattled, display their instability, and become open to resignification' ${ }^{14}$ I want to suggest that the experience of looking at the image on the cover of Gender Trouble, of undergoing the disturbance it provokes, offers an allegory not only for the provocation that can be taken to inhere in such an 'anomalous' scene but also for what we might think of here as the compulsion of response bound to the inherent failure of the norm to fully constitute the 'real'. At times, this failure urges the conservative attempt to maintain the idealities of the norm as reality; at others, as signification and materiality fail to pass through one another seamlessly, as we undergo a dissonance or interval, we might become aware of our own disturbance and the question of how to respond. I might sense my own precarious place in the recitation of gender and respond to that in a range of different ways. There is thus a vital ethical aspect to this question of the 'way of returning' in an unstable field of meaning. ${ }^{15}$

The compulsion of response is a site of potential violence, which might manifest itself as an aggression against the other who does not 'fit' the order of objects in a world in which I find my place, the other whose presence thus disturbs me, and in which context I reaffirm the laws of gendered being or, more broadly, of a social order that gives me my place (consider the likelihood that the girl who

13 Butler, Bodies that Matter, p. 2.

14 Butler, Undoing Gender, p. 28.

15 Compare Sara Salih's account of an 'ethics of difficulty' and especially its bearing on the 'difficulty' critics have regularly encountered in reading Butler's texts (Salih, Sara 2003, 'Judith Butler and the ethics of difficulty', Critical Quarterly, vol. 45, no. 3). 
looks like a boy or the boy in a girl's clothes will be bullied at school). I outline these aspects of Butler's treatment of violence in the next section, alongside Butler's account of non-violence in works such as Precarious Life (2004), Undoing Gender (2004), Giving an Account of Oneself (2005) and Frames of War (2009). Butler stresses that non-violence is a way of undergoing disturbance that matters vitally in the context of experiences of aggression, vulnerability and injury that are irreducible in life. Non-violence, in this account, is not a principle governing action; on the contrary - and in a way that conforms to the account given here of how we might undergo disturbance in the force-fields of normative life - non-violence can be experienced as a 'claim', alongside other rival claims, within a situation that demands response. ${ }^{16}$ This marks the site of a struggle that engages and touches on the conditions of one's own formation, the way in which one's own self appears in the circuitry of norms in ways that never are quite 'one's own'. In Butler's analysis, violence typically inheres in the social formation of selves; however, such formation is not a 'once and for all' process and this affords an ethical opportunity:

We are at least partially formed through violence. We are given genders or social categories, against our will, and these categories confer intelligibility or recognizability, which means that they also communicate what the social risks of unintelligibility or partial intelligibility might be...But... a certain crucial breakage can take place between the violence by which we are formed and the violence with which, once formed, we conduct ourselves...The normative production of the subject is an iterable process - the norm is repeated, and in this sense is constantly 'breaking' with the contexts delimited as the 'conditions of production'. ${ }^{17}$

One way in which Butler characterises the ethical practice of non-violence is as 'making good use of the iterability of productive norms and, hence, of their fragility and transformability ${ }^{18}$ in a context in which we must recognise ourselves as 'mired in violence'. Non-violence, she argues, is a struggle against performing our sensed needs for self-preservation, which we might often seek to secure by 'returning' action in a way that confirms or reiterates violence. In what follows, I aim to connect the idea Butler develops here of the nature of ethical responsibility in scenes characterised by unease, anxiety and ambivalence with a reflection on the experience of what troubles - even in seemingly 'mild' cases, such as the experience of the image on the cover of a book. My argument will be that it would be a mistake to imagine provocation or the sense of trouble simply disappearing from such scenes as we 'see through' the falsity of claims within

16 Butler, Judith 2009, Frames of War: When is life grievable?, Verso, New York and London, p. 165.

17 Ibid., p. 168.

18 Ibid., p. 170. 
them. Instead, I shall elaborate an account of 'apprehension' as the ethical mode in which a disturbing image is encountered. I attempt a reading of Butler here that stresses ways of 'unworking' (as opposed to overcoming) the moralised forms of power that are embedded in a sense of the necessity or naturalness of prevailing social or gender arrangements. This practice of unworking entails occupying 'conflict in a different way', ${ }^{19}$ and it aims, I suggest, to expose or register the 'force-field' of claims and a continuing relation between 'trouble' and forms of disturbance that are productive and creative - a testimony not only to the ever present possibility of violence, but to the social bonds that at once maintain and undo us.

\section{II: violence and non-violence}

As a queer activist and as a member of the board of the San Francisco-based International Gay and Lesbian Human Rights Commission, Butler has taken a significant interest in the multiple forms of violence occasioned against the sexually anomalous, across a wide range of instances - from the phenomenon of gay-bashing to forced corrective surgery for the intersexed: 'What astonished me, time and again,' she writes, 'was how often the organization was asked to respond to immediate acts of violence against sexual minorities, especially when that violence was not redressed in any way by local police or government in various places in the globe. ${ }^{20}$ Discussing violence against the ambiguously gendered (though the form of the account is, as we shall see, extended to other instances), Butler writes:

The desire to kill someone, or killing someone, for not conforming to the gender norm by which a person is 'supposed' to live suggests that life itself requires a set of sheltering norms, and that to be outside it, to live outside it, is to court death. The person who threatens violence proceeds from the anxious and rigid belief that a sense of world and a sense of self will be radically undermined if such a being, uncategorizable, is permitted to live within the social world. The negation, through violence, of that body is a vain and violent effort to restore order, to renew the social world on the basis of intelligible gender, and to refuse the challenge to rethink that world as something other than natural or necessary. ${ }^{21}$

In this passage, violence is being thought about as a process of enforcing the boundaries of what can be regarded as real and permitted to exist; as such, it

19 Ibid., p. 175.

20 Butler, Undoing Gender, p. 34.

21 Ibid. 
participates in actively refusing what is 'contingent, frail, open to fundamental transformation in the gendered order of things' ${ }^{22}$ Within the frame that seems to its perpetrators to legitimate their actions, the victims of such violence are deemed to 'bring it upon themselves', indeed to 'court death' by virtue of their deviancy. The violence enacted against such victims 'disappears' to the precise extent that it is successful in shoring up or restoring an order of intelligibility that denies reality to what seems anomalous, deviant or simply unworthy of living. Such violence marks what it is to be unsupported as a body or life that 'matters', and this in a way that extends beyond these examples of violence related to sexual identity, to many ways of discounting human lifefor instance, in the relations of the First to the Third World or in the context of war. The normative conditions under which certain forms of violence become not only possible, but are, in one way or another, tacitly or explicitly considered justified, link both agencies of the law and those who seemingly act outside it. This is not strictly, then, a psychological thesis about what motivates such violence in individual cases; rather, it rests on ideas about the fundamental constitution of the social world, as the site at which 'reality' is being made and unmade and in ways that are bound up with certain moralising processes. To 'matter' is at once to materialise and to be of some importance; its converse is a process of dematerialisation that simultaneously negates the value and the very possibility of an existence. The moralisation at work in this process intervenes in the realm of appearances to secure a sense of the goodness or rightness of what is always and already there: the real, the natural, the unchangeable, the necessary, the hegemonic order.

There is no question here of there simply being different opinions about what it is right or wrong to do or be (questions of 'morality' in that sense). Rather, something that is in the process of appearing or manifesting itself is quashed, as the very possibility of its taking on embodied form, or existing as a life, is refused (and, importantly, is refused even as the possibility deemed 'impossible' in fact manifests itself). Violence accompanies the life of norms, inhering in their literal enforcement, as well as in the productive shaping of the field of their application; it inheres, moreover, in modes of justification that constitute a warrant for the necessity of action by invoking a certain circularity between how things are and how they must be, where this generates practices and ways of thinking that attempt to conform reality to its 'proper' normative shape. This circular movement takes the meaning of violence beyond that of coercive force and into a field of social power with much broader reach. Nonetheless, as Butler writes in the passage cited above, such violence is 'in vain'; something in it fails. This point is important both in terms of identifying sites at which 
another response becomes possible and in tracing, as it were, negatively, a kind of testimony to the failure of violence to secure the aims it claims for itself. ${ }^{23} \mathrm{We}$ might consider in this light the following example.

One vivid illustration of how normative violence responds to the 'inconceivability' of certain gender configurations is provided in Butler's analysis of what supports a sense of the necessity of the corrective surgery that is practised on intersex children. This assigns a sex to a body that fails to belong 'properly' to either pole of a dimorphic vision of gender. The intervention is deemed essential to achieving social identity and requires remaking the body in the social image of one gender or the other. ${ }^{24}$ Yet the surgery that is performed in the name of creating a viable identity and a 'normal-looking' body typically leaves scars and mutilations, rendering it very questionable how far it will 'pass' for normal at all. To conform to what is supposed to be normal turns out to require significant, often violent, force to bring about what might be no more in the end than a crude approximation. Further, the effort to align bodily appearance with an 'inner' sexual identity-determined by the presence or absence of a ' $\mathrm{Y}$ ' chromosome - presumes the existence of a natural arrangement of sex that is belied by precisely these instances. The naturalness of the sex binary is at once presupposed and restored as ideal in this process. Butler is led to comment, therefore, on the paradoxes whereby the

norms [that] govern intelligible gender...are those that can be forcibly imposed and behaviorally appropriated, so that the malleability of gender construction...turns out to require forceful application. And the 'nature' that the endocrinologists defend also needs a certain assistance through surgical and hormonal means...So in each case, the primary premise is in some ways refuted by the means by which it is implemented. Malleability is, as it were, violently imposed. And naturalness is artificially induced. $^{25}$

Despite, or rather through, these paradoxes, the sense that it is necessary to intervene, to act to align this person, this body, with a fixed and recognisable gender identity, acquires a palpable force. Intervention seems to be required if this being is to enjoy the life of a recognisable human being. This process can then take place with good conscience, indeed righteousness. Although Butler does not deny that these cases pose complicated personal and political dilemmas, she nonetheless wishes to point here both to the social conditions shaping them and to the powerful ideological frame that transmutes a dilemma into a clear mandate for action. There are moral frames that can make the violence of an

23 For a further elaboration of this concept of 'testimony', see: Jenkins, Fiona 2007, 'Toward a nonviolent ethics: a response to Catherine Mills', differences, vol. 18, no. 2.

24 Butler, Undoing Gender, p. 63.

25 Ibid., p. 66. 
intervention 'disappear', as violence becomes the justified means to a valid end. Thus, for instance, within this frame, if we do the violence of extensive and imperfect surgery it is not violence because it brings about a good, and the good is good because within it a natural order of being, a 'truth' of identity both resides and is by this process restored. In this intervention, there is a response not only to an individual but to a field of disturbance, some 'gender trouble', assumed to be in need of pacification through correction. So what would it mean to not see this intervention as necessary? How would this transform the social field of gender?

It is easy to see in this example how this moral scripting of gender might lead those who inhabit its norms to see themselves as bearing only a limited range of possibilities. Butler is respectful of those who choose to try to conform their gender to prevailing norms, while nonetheless raising questions about how we might consider such choices to be 'forced', not merely by external constraint but by the very fundamental desire to appear as recognisable - a recognisability that, as we have seen, could even be a condition of a person's survival. ${ }^{26}$ This issue is at stake not only for the likely victim of social violence, but also for the perpetrator of violence, whose sense of social recognisability also depends on maintaining the norms of intelligibility in place. ${ }^{27}$ The sense of being invested in certain terms of social order is not a superficial or dispensable aspect of the self, on this account; on the contrary, it is a vital dimension of occupying the position of a 'subject':

Bound to seek recognition of its own existence in categories, terms and names that are not of its own making, the subject seeks the sign of its own existence outside itself, in a discourse that is at once dominant and indifferent...Subjection exploits the desire for existence, where existence is always conferred from elsewhere; it marks a primary vulnerability to the Other in order to be. ${ }^{28}$

\footnotetext{
26 See especially the essays in ibid.: 'Doing justice to someone' (pp. 57-74) and 'Undiagnosing gender' (pp. 75-101). Salamon ('The bodily ego and the contested domain of the material', p. 120) comments that 'to insist upon the livability of one's own embodiment, particularly when that embodiment is culturally abject or socially despised, is to undertake a constant and always incomplete labor to transfigure more than just the materiality of our bodies. It is to strive to create the lived meanings of those materialities.'

27 Another illustration of how in a proximate but disavowed relation the other secures a sense of privilege for the self is given by Butler in a reading of Nella Larsen's Passing. Butler examines the dependencies of the figure of the white racist within this novella, married to a woman who 'passes' for white, but is nicknamed by him 'Nig': 'If he associates with her, she cannot be black. But if she associates with blacks, she becomes black, where the sign of blackness is contracted, as it were, through proximity. The added presumption is that if he were to associate with blacks, the boundaries of his own whiteness, and surely that of his children, would no longer easily be fixed. Paradoxically, his own racist passion requires that association; he cannot be white without blacks and without the constant disavowal of his relation to them. It is only through that disavowal that his whiteness is constituted, and through the institutionalization of that disavowal that his whiteness is perpetually — but anxiously - reconstituted' (Butler, Bodies that Matter, p. 171).

28 Butler, Judith 1997, The Psychic Life of Power: Theories in subjection, Stanford University Press, Calif., p. 21.
} 
According to the theoretical position elaborated here, gender is not merely a secondary aspect of a person; rather, gender regulations simultaneously make regular, discipline and survey subjects who are thus, as Foucault argues, produced within normative life and not merely constrained by it. ${ }^{29}$ The subject does not precede such normative regulation, as in the idea that we are inclined to have of ourselves as individuals and moral beings, assuming that we precede the fields of normative claims that stand over against us with their 'oughts' and 'musts'. Rather, normative regulation does not only subjugate, but brings into being and sustains the subject - the 'who' - that turns towards an address in a process of 'subjectivation' that is continuing in a person's life. ${ }^{30}$

This thesis has a number of consequences. For one, it suggests that the field of social power is such that our sense of self is fundamentally at stake in our way of turning towards the 'terms of existence' that a discursive social order offers. ${ }^{31}$ This does not, however, entail a deterministic process if we pay heed to the possibilities of response that open around a way of being addressed. This was a point that became very important for Foucault in his late work on ethics and which is taken up very centrally in the ethical approach elaborated in Butler's Giving an Account of Oneself. Another consequence is that progressive politics cannot be conceived in straightforward terms as the liberation of the 'who', the 'I' or subject from the restrictive constraints of external norms; and that however social life is to be transformed, it must be, in some sense, from within the texture of social and discursive relations. It is thus necessary to register the paradoxes of the fundamental dependency of the subject on relations that it never chose, but that sustain and condition its existence in ways that simultaneously subject and confer agency. ${ }^{32}$ One cannot liberate a 'person' from the strictures of regulatory power, because persons are produced through such power. The question then becomes how (from within) we might rework and undo the capturing effects of norms and the congealment within frames of power that give the appearance of being forms of necessity. This corresponds to the de-centring of a subject that is able to take itself for a 'free' agent only by disavowing these conditions of dependency and the inherent vulnerability they establish.

29 See 'The subject of power' and the 'Two lectures' in Foucault, Michel 1980, Power/Knowledge, Pantheon, New York. Also Foucault, Michel 1977, Discipline and Punish, Pantheon, New York, and Foucault, Michel 1978, History of Sexuality. Volume 1, Vintage, New York. See also Butler's discussion of 'Gender regulations' in Undoing Gender, pp. 40-56.

30 G. W. F. Hegel is clearly another major influence on this set of ideas for Butler, though for reasons of space I cannot go into that here. For an excellent discussion of Hegel's ideas, as relevant to Butler's work, see Lloyd, Judith Butler, pp. 13-23.

31 Butler, The Psychic Life of Power, p. 4.

32 Ibid., p. 2. 
The subject, on Butler's account, exceeds but does not escape social power. ${ }^{33}$ It is in this excess that, she argues, agency lies, inhabiting an uneasy practice of 'repetition and its risks':

The subject is compelled to repeat the norms by which it is produced, but that repetition establishes a domain of risk, for if one fails to reinstate the norm 'in the right way' one becomes subject to further sanction, one feels the prevailing conditions of existence threatened. And yet, without a repetition that risks life - in its current organization - how might we begin to imagine the contingency of that organization, and performatively reconfigure the contours of the conditions of life ${ }^{34}$

Butler's critical project is one of unsettling and de-centring those forms of circular reasoning that produce a sense of necessity, as exemplified by the reading of gender-assignment intervention given above, treating these as a foreclosure of the demand that we respond to the 'challenge that difference delivers' ${ }^{35}$ Her invocation here of the demand for a 'performative reconfiguring' of the conditions of life echoes the description of non-violent response in her work, offering a way of thinking about the potentials opened by the experience of being disturbed that I began to sketch in the previous section. We have seen that in the crudest case of victim and perpetrator and in social relations of power more generally, it becomes important to think about how the grip of attachment to established ways of ordering the realm of intelligibility must be loosened or reworked if certain forms of violence are to be opposed. This account extends to address a wide range of instances, in which disturbance is experienced as provocation and leads to a reaction that seeks to restore those configurations of social power that allow the self a sense of transcending its own vulnerabilities.

Many of Butler's readings of scenes of violence point to the tacit presumption that the victim of violence has provoked an attack. This sense structures the legitimation of violent response, including the retributive response of the United States against Afghanistan in the wake of the attacks of 11 September, in ways that render the military action as a form of self-defence. The analysis of violence in Butler's work thus often begins from outlining what is prima facie a compelling instance of violence, to ask how it 'disappears' as violence, in significant part through a reversal placing the victim in the position of provocateur. In one legal judgment of which Butler gives a detailed rhetorical analysis, what begins as the prosecution condemning as hate speech a certain intimidating action (whereby the Klu Klux Klan placed a burning cross in a black family's backyard) comes in the course of the passage of judgment to be read as a sign that the black family, in 
prosecuting, seeks to 'burn' the principle of the First Amendment - the principle protecting freedom of speech. Vulnerability and aggression change places, such that the black family, whose vulnerability initiated the case, transmutes into provocation - the sign of black aggression against the State. ${ }^{36}$ In a reading of the 1992 trial following the beating of Rodney King by police officers in Los Angeles, Butler demonstrates how King is consistently figured throughout the trial of the police officers involved as an inherently threatening figure. Despite video evidence suggesting that there was nothing obviously provocative in King's helpless succumbing to the extraordinarily violent assault inflicted on him, Butler notes that the prefiguration of King as a profoundly threatening figure who thus 'brings the violence on himself' (who deserves, warrants or demands such 'defensive' violence) structures the original police response and the subsequent considerations of the police officers' trial. ${ }^{37}$ One might also consider here the large number of legal judgments on gay-bashing cases that invoke a 'provocation defence' - that is, a defence arguing that a defendant may be excused from enacting violence against a gay man if he was so provoked or simply sensed himself asthreatened (perhaps by some sort of sexual advance) so that his violent reaction becomes 'understandable'.$^{38}$

This sense of provocation certainly demands critique, but perhaps it should not be dismissed as wrong or interpreted as simply being based on false beliefs. Without doubt, racism or homophobia could be said to be at work here. The question of whether critique would be about enabling us to 'see through' the prejudices that shape racist and homophobic fears, or some other kind of work, is, however, analogous to the question I raised at the beginning about the response to Gender Trouble's cover image. My argument here is that part of the importance of Butler's theorisation of these questions is that the deep roots of the sense of provocation in a sense of self and one's dependent status within a wider social order are registered in a significant way. The question then becomes how that provocation and the aggression that accompanies it might be moderated, redirected or un-worked at the level of a transformation in social norms, as well as through work on the self that engages the sense of disturbance. ${ }^{39}$

The conditions of possibility of entering this process include accepting one's relational dependence, one's vulnerability before the other, one's 'haunting' by the inassimilable remainders of socially coherent subject positions. These

36 Butler, Judith 1997, Excitable Speech: A politics of the performative, Routledge, New York and London, pp. 54-61.

37 Butler, Judith 1993, 'Endangered/endangering: schematic racism and white paranoia', in Robert Gooding Williams (ed.), Reading Rodney King/Reading Urban Uprising, Routledge, New York.

38 For an excellent discussion of this and its links to the Rodney King case, see Mills, Catherine 2003, The politics of mere life, Unpublished PhD thesis, The Australian National University, Canberra, pp. 5-9.

39 It is worth stressing Butler's insistence on the point that aggression is irreducible, such that non-violence is the struggle with one's own aggression - to redirect it as concern for justice, rather than fully suppress it. See especially Butler, Frames of War, ch. 5. 
conditions are particularly foregrounded in some recent writing that seeks to establish the terms on which we might think responsibly without beginning from the idea of a subject who 'contracts' this relation to others through an act of will..$^{40}$ Instead, Butler foregrounds the constitutive vulnerability of the subject as the mode of ethicality, and this is a way of reaching towards

a more general conception of the human...one in which we are, from the start, given over to the other...hence, vulnerable to violence; but also vulnerable to another range of touch, a range that includes the eradication of our being at the one end, and the physical support for our lives at the other. ${ }^{41}$

The conception of the human outlined here and elsewhere in Butler's work couples a figure of vulnerability to a kind of open-endedness or futurity. Acknowledging that the subject is always in process-never simply a selfidentical being, but incurring and sustaining vital social bonds by virtue of being 'thrown' into sociality - Butler approaches the sites of disturbance and the claims they seem to generate from another side. As we saw earlier, the form of violence that engages in the repeated effort to restore the 'order' of normative life, she argues, proceeds from an 'anxious and rigid belief that a sense of world and a sense of self will be radically undermined if such a being, uncategorizable, is permitted to live within the social world'. ${ }^{42}$ We might say this disturbance proves intolerable or we might say that the desire to preserve the social order in which the self finds its place is powerfully reasserted; in either case, it issues in a violence that is reiterative and law maintaining in character. To open the possibility of another response, Butler suggests, we must ask:

What might it mean to learn to live in the anxiety of that challenge, to feel the surety of one's epistemological and ontological anchor go, but to be willing, in the name of the human, to allow the human to become something other than what it is traditionally assumed to be ${ }^{43}$

Butler formulates this ethical transition as a passage into 'unknowing', which is also a suspension of a definitive answer to any question about 'what we are'. The acknowledgment of vulnerability within it (the impossibility of fully securing the self or restabilising the social order) marks this thinking as immediately ethical, insofar as refusal of that acknowledgment is at the heart of disavowed violence. Moreover, there is a difference between knowledge and the 'unknowing' of acknowledgment that is important here; the human as 'becoming

\footnotetext{
40 See especially Butler, Judith 2005, Giving an Account of Oneself, Fordham University Press, New York.

41 Butler, Judith 2004, Precarious Life: The powers of mourning and violence, Verso, New York and London, p. 31.

42 Butler, Undoing Gender, p. 34.

43 Ibid., p. 35.
} 
something other than what it was traditionally assumed to be' is futural. The terms on which we might become attuned to our common vulnerability thus escape representation; to reach them we must try to subvert the 'constitutive power' of our own discourse ${ }^{44}$ in the direction of accepting the open-endedness of encounter. ${ }^{45}$ We must learn to engage the other in the open-endedness of the question who are you? As Butler elaborates this thought, a non-violent response to disturbance must learn to

live with its unknowingness about the Other in the face of the Other, since sustaining the bond that the question ['Who are you?'] opens is finally more valuable than knowing in advance what holds us in common, as if we already have all the resources we need to know what defines the human, what its future life might be. ${ }^{46}$

To illustrate one way we might imagine the futural bond sketched here, let me return again to my opening discussion. Perhaps the photograph also creates a space in which the question is presented of how to respond in ways that do not ask 'what is this?' but ask 'who are you?' and thereby refuse to reinstate the existing law of identity but wonder about an unknown future, unfolding from alterity. Thus, although it might well be that my 'captivation' by this image could take the form of a disturbance that will see the boy in girls' clothes or the girl with a boy's face as monstrous, anomalous or in need of correction, this sense of compulsion might also take on another energetic dimension, perhaps one of critical questioning, perhaps one in which this anomalous face starts to look at me in another way. The potential that appears here, however, is perhaps not well captured by the term 'contingency', unless we inscribe this very clearly as what might open in the gesture of return itself - that is, in the way of returning to a troubling or problematic image, one that shows something its own frame cannot quite manage or contain. Contingency in this latter sense emerges, not out of the fact that there are multiple possible identities that the law of gender's either/or somehow conceals, ${ }^{47}$ but rather, out of the very instability of the field of meaning, as an uncertain futural dimension that is irreducibly a part of normative life. This can be figured as the rupture of normativity with itself, its self-fissuring that is the condition of its reproducibility. At stake in it is a political futurity that is not simply a function of the proliferation and pluralisation of identities, but rather an insistence on the importance of the disorientation that comes from losing a certain centring effect of knowledge. In this account, then, it is not that we must simply 'value all possible permutations of the human', but rather it is

\footnotetext{
44 Butler, Precarious Life, p. 43.

45 Ibid., p. 44.

46 Butler, Undoing Gender, p. 35.

47 See ibid. (p. 43) for Butler's comment on the problems of viewing gender as a question of number- that is, 'the multiplication of genders' that displaces the binary scheme, and her preference for Luce Irigaray's theorisation of sex as non-quantitative or of interstitial and transitional modes of 'passage' between genders.
} 
necessary to avow, as Butler puts it, 'that one's own position is not sufficient to elaborate the spectrum of the human, that one must enter into a collective work in which one's own status as a subject must... become disoriented, exposed to what it does not know'. ${ }^{48}$

This avowal works less against than within the desire to normalise the scene, to discern its underlying reality, to find the 'right' answer. It might be described as an 'un-working' of that desire, its release or transformation through an exposure to or a mode of undergoing an experience. Instead of contingency as simply the antithesis of necessity, contingency is better figured in this frame as the sensate opening within the norm, the mobilisation of what it 'touches' on, an engagement otherwise with the claim within it. To figure this again in terms of the disturbance of the photograph, the image stages a certain experience of a decision or of the desire for a decision based on the claim to know what is right, brought face to face with its own impossibility, its sensate limitations. This point is put in another of Butler's essays (Precarious Life) in terms of the image that 'must not only fail to capture its referent but show this failing' ${ }^{49}$ In my reading, this is another rendering of the 'trouble' that links some of the elements of Butler's early work to themes that appear in her most recent work, and this, as I explore in the next section, pays notable attention to the life and power of images.

\section{III: Apprehension and the critical image}

In Frames of War (2009), Butler is very explicitly interested in the questions posed by the images and frames through which 'reality effects' are conveyed and she seeks to articulate what a 'critical image' would look like. These questions were initiated in Precarious Life (2004). In the context of a discussion of the mainstream media's portrayal of war, Butler suggests that the critical image counters the 'triumphalist image' when the latter is an image that allows us a clear point of identification with a 'we' and that 'captures' the human being by making it stand for an idea. ${ }^{50}$ Contrasting and undoing this, the critical image 'must not only fail to capture its referent, but show this failing'. ${ }^{51}$ Invoking Levinas, Butler extends his account of the ethical relation to the face of the other to suggest that the key issue here is the dissonance between the face and the work of representation, generating a paradoxical space. When we seek to

48 Butler, Undoing Gender, p. 36.

49 Butler, Precarious Life, p. 146.

50 Ibid., p. 145.

51 Ibid., p. 146. 
approach the human, 'there is something unrepresentable that we nevertheless seek to represent, and that paradox must be retained in the representation that we give' ${ }^{52}$

In the account that I have been giving of Butler's work, the relation to others is always inhabited by traces of trouble and thus by the ethical dimension of disturbance. In her work in the past decade, this is increasingly mapped onto what Levinas calls the 'radical alterity' and the futural unknown-ness of the other. Here the claims of desiring affective life come to the fore as elements of ethical sensibility, involving both sensitivity and resilience in the face of that which troubles us in the other and a willingness, moreover, to 'carry on' or continue to inhabit this space, which is one of anxiety and struggle with our own murderous desires. ${ }^{53}$ Clarifying, in the context of a discussion of nonviolence, that her claim is not that norms act in deterministic ways, Butler argues that the post-structuralist idea of iterability involves a "preoccupation with notions such as living on, carrying on, carrying over, continuing, that form the temporal tasks of the body' ${ }^{54}$ Within the futural life of norms, we might seek to survive without clinging to the given (and often hostile) terms of selfpreservation. The ambivalences attendant on occupying such spaces find a characterisation in a term she has begun to foreground and treat thematically as cutting across the given terms of recognisability. In Frames of War, 'apprehension' is contrasted with 'recognition'; we can apprehend what we cannot yet recognise. ${ }^{55}$ Apprehension registers a corporeal attunement to that which does not quite appear. In this way, to be apprehensive could be to sense a threat - to be troubled by something approaching, even simply to feel the desire to flee. I suggest that forming around such apprehension, Butler develops an ethics of disturbance that has a vital resonance in the contemporary world - an ethics that seeks out the remaindered bodies of specifically moralised forms of violence and the occlusion of this violence in 'triumphalist' representations.

The violence such an ethics opposes is accompanied by a sense of righteousness or entitlement, and one should recall that the latter is also the site of good conscience regarding violence as legitimate means to valid ends. Yet intrinsic to it is the privilege of one body's needs, security and rights over those of another, one self's sense of its place in the world to the exclusion of that of others and the resolution of disturbance into the maintenance of established order. In this context, one might think of ethical apprehension as attending to what exceeds the nexus of power/knowledge that forms the frames of legitimating privilege. Such apprehension might seem to be a kind of perceptiveness; yet in

52 Ibid., p. 144.

53 Butler, Frames of War, ch. 5.

54 Ibid., p. 169.

55 Ibid., pp. 4-5. 
consequential ways, this risks mis-describing apprehension as the capacity of a subject who might see, feel and be moved or as an element in a sentimental response. An ethics of disturbance, however, evokes conditions that precede capacities attributable to a subject. Apprehension, I suggest, is a modality of ethical corporeality that is internally bound to the critique of violence against remaindered or 'unliveable' lives, insofar as it subsists in a tarrying with, or being exposed to, their disturbance. Beginning in response, at stake in it is a form of responsibility characterised rather by its temporal and material inscription than by reference to the emotive or cognitive states of a subject of experience. Responsibility, as I have sketched Butler's account of it here, inheres in the way of returning to or inhabiting a site of disturbance; and within this, importantly, ethical apprehension responds to the remaindered bodies of righteous violence not primarily by asserting another form of privilege, another right, but by acknowledgment of a social bond, of being in a shared space and time, which, for the very reason of being shared, is futural and responsive. This is the 'bond' of which Butler speaks as being premised on 'unknowing' and of bringing us to awareness of a common corporeal vulnerability. ${ }^{56}$

Thus, in her most recent works on war, Butler places heavy stress on the part that images play in bringing a polity to experience the bodily affects of exposure; shock, outrage, remorse and grief can change the landscape of opinion overnight. What ends public support for a war could even be just one image: the child running, burning and wounded from napalm in Vietnam; the hooded victim of torture at Abu Ghraib. Through such an image, somehow the moral world capable of legitimating war collapses - and not simply, on this account, because the moral sanctity of the nation's involvement in the war has been brought into question by particular, unconscionable acts. Rather, something shows in the image that disrupts the visual field on which the confidence of identity is built, that field in which 'I' or 'we' can believe we are who we are because the image of ourselves is given back to us on terms we acknowledge and recognise. Support for the war evaporates as the nakedness of its violence becomes visible; but further, it dissolves through the temporary incapacity of a shocked public to return the world to a former state of imagined order.

This collapse, which is bodily and visceral and can be only very temporary, is analysed by Butler in terms of an encounter with what lies outside the 'frame' by which the world is presented to the view of a spectatorial public. These images that have become emblematic of a morally 'failed' war are 'pictures we were not supposed to see'. ${ }^{57}$ If this aspect of the account seems to stress an overtly censorial function of the nexus of media and state in providing the legitimating frame of war, we should again be wary of relying too heavily on the

56 See especially the essay 'Violence, mourning, politics' in Butler, Precarious Life, pp. 19-49.

57 Butler, Precarious Life, p. 150. 
idea of suddenly seeing through the falsehoods of a normative frame in order to arrive at the truth, for this does not fully account for the collapse in the attitude of righteousness, which after all is capable of upholding its stance through disavowal, even in the face of massive contradictory evidence. If we take up the term 'apprehension' to think through this question, however, perhaps one can say that what takes place in a collapse induced by the critical image bears its ethical significance and political potential in and through the image's capacity to convey a certain sort of awareness of the body and its common vulnerability. This is something that is figured through the image, rather than shown as such; 'despite their graphic effectivity', Butler writes of the Vietnam War images, they 'pointed somewhere else, beyond themselves, to a life and to a precariousness that they could not show' ${ }^{58}$ We apprehend vulnerability through the disturbance of the image, and not, as it were, as an element of the content depicted.

Thus, in a world in which our cultural frames for thinking the human are, like our framing of gender, constituted such that some lives do not count as lives, Butler is not first and foremost engaged in arguing the idea that representation must be extended to include those hitherto excluded from the image of the human, or expanded by multiplying possibilities that have an abstract form. Rather, as I have sought to illumine here, what she is seeking to theorise is something taking place at the borders of representation, at the point of its failure and marking the antagonism that attends the questions 'What is real? Whose lives are real? How might reality be remade?'59 As Butler remarks in Bodies that Matter, here we encounter a limit of 'construction' that must be elaborated by thinking as much about how bodies are not constructed as how they are, and to what ends, within what economies of validation. ${ }^{60}$ And perhaps, I have been suggesting, it is this vulnerability of the body within continuing processes of realisation and derealisation that shows up in the dissonant image, the picture at odds with itself that captures, disturbs and moves us. In Butler's account, ethics requires us to risk ourselves precisely at such 'moments of unknowingness; when what forms us diverges from what lies before us; when our willingness to become undone in relation to others constitutes our chance of becoming human' ${ }^{61}$ It is this, to return us to my epigraph, that places us in a 'predicament' we cannot solve, but which lays us open to the claims of others. As such, a kind of contestability of oneself lies at the heart of this ethics - an openness to the claims of others that is correlative with the experience of vulnerability.

This essay, then, has sought to give some indication of how, in an extensive body of writing that has branched out from a focus on the questions of sexuality, sex

58 Ibid.

59 Butler, Precarious Life, p. 33.

60 Butler, 'Endangered/endangering', p. 16.

61 Butler, Giving an Account of Oneself, p. 136. 
and gender (for which she is undoubtedly most famous) to consideration in recent work of the frames of justification that serve to legitimate wars, Butler offers a broad interrogation of the violence that structures and haunts many aspects and manifestations of contemporary political and ethical life. The issue I have tried to clarify is the centrality to Butler's argument of the question of what sorts of relationship we are able to establish with that which claims us, or, in other words, with that which has authority for us, that which compels us within the space of normative life. Perhaps this would amount to asking: how might we open this life out to a future that is not 'unknown' in a purely abstract sense, but responds to the troubling experience of difference nonviolently? Can we exist in a way that is exposed to dissonance and yet able to imagining surviving, even flourishing, within its living potentiality? And can our apprehension be endured and undergone in ways that mark our opening to exposure, in lieu of its anxious, often violent, refusal? Butler's answer to these questions is not an easy 'yes'. It would be better to say that her work offers an invitation to the struggle. 